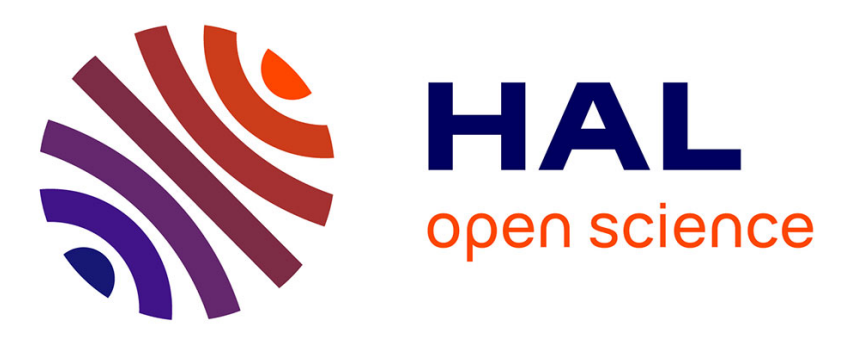

\title{
The influence of sintering temperature on the proliferation of fibroblastic cells in contact with HA-bioceramics
}

P. Frayssinet, N. Rouquet, Jacques Fages, M. Durand, P. Vidalain, G. Bonel

\section{- To cite this version:}

P. Frayssinet, N. Rouquet, Jacques Fages, M. Durand, P. Vidalain, et al.. The influence of sintering temperature on the proliferation of fibroblastic cells in contact with HA-bioceramics. Journal of Biomedical Materials Research, 1997, 35 (3), pp.337-347. 10.1002/(SICI)10974636(19970605)35:33.0.CO;2-I . hal-01803521

\section{HAL Id: hal-01803521 \\ https://hal.science/hal-01803521}

Submitted on 30 May 2018

HAL is a multi-disciplinary open access archive for the deposit and dissemination of scientific research documents, whether they are published or not. The documents may come from teaching and research institutions in France or abroad, or from public or private research centers.
L'archive ouverte pluridisciplinaire HAL, est destinée au dépôt et à la diffusion de documents scientifiques de niveau recherche, publiés ou non, émanant des établissements d'enseignement et de recherche français ou étrangers, des laboratoires publics ou privés. 


\title{
The influence of sintering temperature on the proliferation of fibroblastic cells in contact with HA-bioceramics
}

\author{
P. Frayssinet, ${ }^{1,2, *}$ N. ${ }^{1}$ ouquet, ${ }^{1}$ J. Fages, ${ }^{1}$ M. Durand,${ }^{1}$ P. O. Vidalain, ${ }^{1}$ and G. Bonel ${ }^{1}$ \\ ${ }^{1}$ Bioland, 132 rte d'Espagne, 31100 Toulouse; ${ }^{2}$ Laboratoire du Tissu Calcifié et des Pathologies Ostéoarticulaires, \\ Université Paul Sabatier, Toulouse, France
}

HA-ceramics used in human surgery as osteoconductive surfaces show a great variety of characteristics. Certain characteristics such as grain size, porosity, and surface area, are controlled by the sintering temperature of the slurry. We grew L-929 fibroblast cells on HA-ceramic disks that had been sintered at different temperatures ranging from $850^{\circ}-$ $1350^{\circ} \mathrm{C}$. The cell line growth rate was lower on ceramic disks than on the culture-grade polystyrene used as a negative control. Cell growth correlated with the ceramic sintering temperature although no significant difference in the cell adhesion to the different ceramics was shown. Growth rate on ceramics sintered at low temperatures $\left(850^{\circ}\right.$ and $\left.950^{\circ} \mathrm{C}\right)$ was negative whereas it was positive on disks sintered at higher temperatures. When the cells were separated from the disks by a polycarbonate membrane, the growth rate was negative on those membranes in contact with lowtemperature sintered disks and positive on the hightemperature sintered disks. The calcium and phosphorus

\section{INTRODUCTION}

HA-ceramics are used in human surgery as osteoconductive materials that can guide and expand the bone-healing tissue when used as a porous bone substitute. ${ }^{1}$ These materials are of limited application because they are very brittle and difficult for the surgeon to shape. Furthermore, the osseointegration process observed in relatively small bone defects produced in healthy animals is difficult theoretically to extrapolate to humans due to the absence of osteogenic tissue at the site of implantation. Optimization of the calcium phosphate ceramic characteristics would seem necessary in these difficult cases to improve osseointegration.

Several characteristics, i.e. grain size, porosity, and surface area, are dependent on the sintering temperature of the slurry. We chose to study the effect of sin-

*To whom correspondence should be addressed. concentration in the culture medium in contact with ceramics sintered below $1050^{\circ} \mathrm{C}$ decreased during the culture period. Ceramics sintered between $1100^{\circ}$ and $1250^{\circ} \mathrm{C}$ brought about an increase in $\mathrm{Ca}$ and $\mathrm{P}$ concentrations while ceramics sintered at higher temperatures did not induce any changes. SEM examination of the $850^{\circ}$ and $1200^{\circ} \mathrm{C}$ sintered ceramics showed that the $850^{\circ} \mathrm{C}$ sintered ceramics consisted of small grains with pores between them and the $1200^{\circ} \mathrm{C}$ sintered ceramics were made of larger grains without any visible pores, thereby decreasing the surface of material in contact with the culture medium. This difference in surface area was confirmed by the fact that the amount of albumin adsorbed onto the ceramic was dependent on the sintering temperature. In conclusion, the modification of the culture medium brought about by high-surfaced ceramics could influence the growth of cells with which such ceramics come in contact.

tering temperature on ceramic cytocompatibility as evaluated in vitro.

Isolated cell growth at the contact point of materials is considered to be an index of a material's cytocompatibility. In recent years, a consistent number of cell cultures have been grown in contact with HAceramics with very different characteristics. Many reports have shown that several either primary or established cell lines may sustain growth on HA or calcium phosphate ceramics. The ceramics used in these studies, however, were poorly characterized, so the lack of information about the ceramics and also the absence of controls make it impossible to relate the characteristics of the materials to those of the growth characteristics. ${ }^{2-5}$ Hyakuna et al. ${ }^{6}$ showed that a cytostatic effect or even cell death could occur when cells were grown in contact with HA-ceramics sintered at low temperatures. The data given in this report did not permit any definite correlation between the ceramic characteristics and growth of the cell line, however.

We grew fibroblastic cells at the surface of dense 
TABLE IA

Parametric Mean (x) of Cell Number Obtained at Each Period of Time on the Different Temperature Sintered Disks (sx = Variance; $\sigma x=$ Standard Deviation)

\begin{tabular}{|c|c|c|c|c|}
\hline Sample & 20 Hours & 72 Hours & 144 Hours & 336 Hours \\
\hline Control & $\begin{aligned} x & =85.66 \\
s x & =9.81 \\
\sigma x & =8.01 \\
\Sigma x & =257 \\
\Sigma x^{2} & =22209 \\
n & =3 \\
x_{m i} & =80 \\
x_{m a} & =97\end{aligned}$ & $\begin{aligned} \mathrm{x} & =\mathbf{4 2 3 . 3 3} \\
\mathrm{sx} & =25.16 \\
\sigma \mathrm{x} & =20.54 \\
\Sigma \mathrm{x} & =1270 \\
\Sigma \mathrm{x}^{2} & =538900 \\
\mathrm{n} & =3 \\
\mathrm{x}_{\mathrm{mi}} & =400 \\
\mathrm{x}_{\mathrm{ma}} & =450\end{aligned}$ & $\begin{aligned} \mathbf{x} & =\mathbf{1 2 2 0 . 3 3} \\
\mathrm{sx} & =20 \\
\sigma \mathrm{x} & =16.33 \\
\Sigma \mathrm{x} & =3661 \\
\Sigma \mathrm{x}^{2} & =4468441 \\
\mathrm{n} & =3 \\
\mathrm{x}_{\mathrm{mi}} & =1200 \\
\mathrm{x}_{\mathrm{ma}} & =1240\end{aligned}$ & $\begin{aligned} \mathrm{x} & =\mathbf{1 2 6 6 . 6 6} \\
\mathrm{sx} & =208.16 \\
\sigma \mathrm{x} & =169.96 \\
\Sigma \mathrm{x} & =3800 \\
\Sigma \mathrm{x}^{2} & =4900000 \\
\mathrm{n} & =3 \\
\mathrm{x}_{\mathrm{mi}} & =1100 \\
\mathrm{x}_{\mathrm{ma}} & =1500\end{aligned}$ \\
\hline 850 & $\begin{aligned} \mathrm{x} & =55.25 \\
\mathrm{sx} & =14.33 \\
\sigma \mathrm{x} & =11.7 \\
\Sigma \mathrm{x} & =165.77 \\
\Sigma \mathrm{x}^{2} & =9570.82 \\
\mathrm{n} & =3 \\
\mathrm{x}_{\mathrm{mi}} & =38.78 \\
\mathrm{x}_{\mathrm{ma}} & =64.13\end{aligned}$ & $\begin{aligned} \mathbf{x} & =\mathbf{1 8 . 1 5} \\
\mathrm{sx} & =18.15 \\
\sigma \mathrm{x} & =14.81 \\
\Sigma \mathrm{x} & =54.45 \\
\Sigma \mathrm{x}^{2} & =1647.11 \\
\mathrm{n} & =3 \\
\mathrm{x}_{\mathrm{mi}} & =0 \\
\mathrm{x}_{\mathrm{ma}} & =36.3\end{aligned}$ & $\begin{aligned} \mathbf{x} & =\mathbf{3 0 . 6 5} \\
\mathrm{sx} & =12.12 \\
\sigma \mathrm{x} & =9.89 \\
\Sigma \mathrm{x} & =91.96 \\
\Sigma \mathrm{x}^{2} & =3112.67 \\
\mathrm{n} & =3 \\
\mathrm{x}_{\mathrm{mi}} & =18.15 \\
\mathrm{x}_{\mathrm{ma}} & =42.35\end{aligned}$ & $\begin{aligned} \mathbf{x} & =\mathbf{2 2 . 1 8} \\
\mathrm{sx} & =3.49 \\
\sigma \mathrm{x} & =2.85 \\
\Sigma \mathrm{x} & =66.55 \\
\Sigma \mathrm{x}^{2} & =1500.7 \\
\mathrm{n} & =3 \\
\mathrm{x}_{\mathrm{mi}} & =18.15 \\
\mathrm{x}_{\mathrm{ma}} & =24.2\end{aligned}$ \\
\hline 950 & $\begin{aligned} \mathrm{x} & =\mathbf{5 3 . 6 4} \\
\mathrm{sx} & =17.3 \\
\sigma \mathrm{x} & =14.13 \\
\Sigma \mathrm{x} & =160.93 \\
\Sigma \mathrm{x}^{2} & =9231.88 \\
\mathrm{n} & =3 \\
\mathrm{x}_{\mathrm{mi}} & =35.91 \\
\mathrm{x}_{\mathrm{ma}} & =70.49\end{aligned}$ & $\begin{aligned} \mathbf{x} & =\mathbf{2 4 . 3 8} \\
\mathrm{sx} & =13.84 \\
\sigma \mathrm{x} & =11.3 \\
\Sigma \mathrm{x} & =73.15 \\
\Sigma \mathrm{x}^{2} & =2166.9 \\
\mathrm{n} & =3 \\
\mathrm{x}_{\mathrm{mi}} & =13.3 \\
\mathrm{x}_{\mathrm{ma}} & =39.9\end{aligned}$ & $\begin{aligned} \mathrm{x} & =\mathbf{4 0 . 3 6} \\
\mathrm{sx} & =12.6 \\
\sigma \mathrm{x} & =10.3 \\
\Sigma \mathrm{x} & =121.1 \\
\Sigma \mathrm{x}^{2} & =5206.25 \\
\mathrm{n} & =3 \\
\mathrm{x}_{\mathrm{mi}} & =28 \\
\mathrm{x}_{\mathrm{ma}} & =53.2\end{aligned}$ & $\begin{aligned} \mathbf{x} & =\mathbf{3 1 . 0 3} \\
\mathrm{sx} & =3.83 \\
\sigma \mathrm{x} & =3.13 \\
\Sigma \mathrm{x} & =93.1 \\
\Sigma \mathrm{x}^{2} & =2918.7 \\
\mathrm{n} & =3 \\
\mathrm{x}_{\mathrm{mi}} & =26.6 \\
\mathrm{x}_{\mathrm{ma}} & =33.25\end{aligned}$ \\
\hline 1050 & $\begin{aligned} \mathrm{x} & =\mathbf{5 1 . 1 5} \\
\mathrm{sx} & =4.55 \\
\sigma \mathrm{x} & =3.71 \\
\Sigma \mathrm{x} & =153.47 \\
\Sigma \mathrm{x}^{2} & =7892.45 \\
\mathrm{n} & =3 \\
\mathrm{x}_{\mathrm{mi}} & =46.19 \\
\mathrm{x}_{\mathrm{ma}} & =55.13\end{aligned}$ & $\begin{aligned} \mathrm{x} & =\mathbf{2 1 5 . 3} \\
\mathrm{sx} & =98.4 \\
\sigma \mathrm{x} & =80.33 \\
\Sigma \mathrm{x} & =645.9 \\
\Sigma \mathrm{x}^{2} & =158424 \\
\mathrm{n} & =3 \\
\mathrm{x}_{\mathrm{mi}} & =145.3 \\
\mathrm{x}_{\mathrm{ma}} & =327.8\end{aligned}$ & $\begin{aligned} \mathrm{x} & =\mathbf{4 2 2 . 1 6} \\
\mathrm{sx} & =56.41 \\
\sigma \mathrm{x} & =46.05 \\
\Sigma \mathrm{x} & =1266.5 \\
\Sigma \mathrm{x}^{2} & =541038 \\
\mathrm{n} & =3 \\
\mathrm{x}_{\mathrm{mi}} & =357.6 \\
\mathrm{x}_{\mathrm{ma}} & =461.9\end{aligned}$ & $\begin{aligned} \mathrm{x} & =\mathbf{9 2 8 . 7 6} \\
\mathrm{sx} & =99.20 \\
\sigma \mathrm{x} & =81 \\
\Sigma \mathrm{x} & =2786.3 \\
\Sigma \mathrm{x}^{2} & =2607507 \\
\mathrm{n} & =3 \\
\mathrm{x}_{\mathrm{mi}} & =864.2 \\
\mathrm{x}_{\mathrm{ma}} & =1043\end{aligned}$ \\
\hline 1150 & $\begin{aligned} \mathrm{x} & =\mathbf{7 7 . 6 9} \\
\mathrm{sx} & =19.44 \\
\sigma \mathrm{x} & =15.87 \\
\Sigma \mathrm{x} & =233.09 \\
\sum \mathrm{x}^{2} & =18866.64 \\
\mathrm{n} & =3 \\
\mathrm{x}_{\mathrm{mi}} & =55.42 \\
\mathrm{x}_{\mathrm{ma}} & =91.28\end{aligned}$ & $\begin{aligned} \mathrm{x} & =353.16 \\
\mathrm{sx} & =82.04 \\
\sigma \mathrm{x} & =66.98 \\
\Sigma \mathrm{x} & =1059.5 \\
\Sigma \mathrm{x}^{2} & =387641 \\
\mathrm{n} & =3 \\
\mathrm{x}_{\mathrm{mi}} & =277.1 \\
\mathrm{x}_{\mathrm{ma}} & =440.1\end{aligned}$ & $\begin{aligned} \mathbf{x} & =\mathbf{7 1 1 . 7 3} \\
\mathrm{sx} & =286.26 \\
\sigma \mathrm{x} & =233.73 \\
\Sigma \mathrm{x} & =2135.2 \\
\Sigma \mathrm{x}^{2} & =1683589 \\
\mathrm{n} & =3 \\
\mathrm{x}_{\mathrm{mi}} & =440 \\
\mathrm{x}_{\mathrm{ma}} & =1010.6\end{aligned}$ & $\begin{aligned} \mathbf{x} & =\mathbf{1 3 6 9 . 2} \\
\mathrm{sx} & =197.62 \\
\sigma \mathrm{x} & =161.36 \\
\Sigma \mathrm{x} & =4107.6 \\
\Sigma \mathrm{x}^{2} & =5702238 \\
\mathrm{n} & =3 \\
\mathrm{x}_{\mathrm{mi}} & =1141 \\
\mathrm{x}_{\mathrm{ma}} & =1483.3\end{aligned}$ \\
\hline 1200 & $\begin{aligned} \mathrm{x} & =\mathbf{6 3 . 9 6} \\
\mathrm{sx} & =16.64 \\
\sigma \mathrm{x} & =13.58 \\
\Sigma \mathrm{x} & =191.88 \\
\Sigma \mathrm{x}^{2} & =12826.7 \\
\mathrm{n} & =3 \\
\mathrm{x}_{\mathrm{mi}} & =49.2 \\
\mathrm{x}_{\mathrm{ma}} & =82\end{aligned}$ & $\begin{aligned} \mathrm{x} & =\mathbf{2 8 4 . 2 6} \\
\mathrm{sx} & =96.09 \\
\sigma \mathrm{x} & =78.46 \\
\Sigma \mathrm{x} & =852.8 \\
\Sigma \mathrm{x}^{2} & =260891 \\
\mathrm{n} & =3 \\
\mathrm{x}_{\mathrm{mi}} & =213.2 \\
\mathrm{x}_{\mathrm{ma}} & =393.6\end{aligned}$ & $\begin{aligned} \mathbf{x} & =\mathbf{7 5 4 . 4} \\
\mathrm{sx} & =198.83 \\
\sigma \mathrm{x} & =162.35 \\
\sum \mathrm{x} & =2263.2 \\
\Sigma \mathrm{x}^{2} & =1786432 \\
\mathrm{n} & =3 \\
\mathrm{x}_{\mathrm{mi}} & =541.2 \\
\mathrm{x}_{\mathrm{ma}} & =934.8\end{aligned}$ & $\begin{aligned} \mathrm{x} & =\mathbf{1 4 4 3 . 2} \\
\mathrm{sx} & =118.26 \\
\sigma \mathrm{x} & =96.56 \\
\Sigma \mathrm{x} & =4329.6 \\
\Sigma \mathrm{x}^{2} & =6276450 \\
\mathrm{n} & =3 \\
\mathrm{x}_{\mathrm{mi}} & =1312 \\
\mathrm{x}_{\mathrm{ma}} & =1541.6\end{aligned}$ \\
\hline 1250 & $\begin{aligned} \mathrm{x} & =\mathbf{6 2 . 3 2} \\
\mathrm{sx} & =24.49 \\
\sigma \mathrm{x} & =19.99 \\
\Sigma \mathrm{x} & =186.96 \\
\Sigma \mathrm{x}^{2} & =12850.9 \\
\mathrm{n} & =3 \\
\mathrm{x}_{\mathrm{mi}} & =34.44 \\
\mathrm{x}_{\mathrm{ma}} & =80.36\end{aligned}$ & $\begin{aligned} \mathrm{x} & =\mathbf{3 0 6 . 6 8} \\
\mathrm{sx} & =115.11 \\
\sigma \mathrm{x} & =93.99 \\
\Sigma \mathrm{x} & =920.04 \\
\Sigma \mathrm{x}^{2} & =308661.18 \\
\mathrm{n} & =3 \\
\mathrm{x}_{\mathrm{mi}} & =173.84 \\
\mathrm{x}_{\mathrm{ma}} & =377.2\end{aligned}$ & $\begin{aligned} \mathrm{x} & =\mathbf{8 3 6 . 4} \\
\mathrm{sx} & =214.45 \\
\sigma \mathrm{x} & =175.1 \\
\Sigma \mathrm{x} & =2509.2 \\
\Sigma \mathrm{x}^{2} & =2190679.2 \\
\mathrm{n} & =3 \\
\mathrm{x}_{\mathrm{mi}} & =688.8 \\
\mathrm{x}_{\mathrm{ma}} & =1082.4\end{aligned}$ & $\begin{aligned} \mathrm{x} & =\mathbf{1 3 9 4} \\
\mathrm{sx} & =295.65 \\
\sigma \mathrm{x} & =241.4 \\
\Sigma \mathrm{x} & =4182 \\
\Sigma \mathrm{x}^{2} & =6004532 \\
\mathrm{n} & =3 \\
\mathrm{x}_{\mathrm{mi}} & =1148 \\
\mathrm{x}_{\mathrm{ma}} & =1722\end{aligned}$ \\
\hline
\end{tabular}


TABLE IA

Continued

\begin{tabular}{|c|c|c|c|c|}
\hline Sample & 20 Hours & 72 Hours & 144 Hours & 336 Hours \\
\hline 1300 & $\begin{aligned} \mathrm{x} & =\mathbf{6 2 . 8 6} \\
\mathrm{sx} & =10.91 \\
\sigma \mathrm{x} & =8.91 \\
\Sigma \mathrm{x} & =188.6 \\
\Sigma \mathrm{x}^{2} & =12095.13 \\
\mathrm{n} & =3 \\
\mathrm{x}_{\mathrm{mi}} & =55.76 \\
\mathrm{x}_{\mathrm{ma}} & =75.44\end{aligned}$ & $\begin{aligned} \mathbf{x} & =\mathbf{5 2 6 . 6} \\
\mathrm{sx} & =95.94 \\
\sigma \mathrm{x} & =78.34 \\
\Sigma \mathrm{x} & =1579.52 \\
\Sigma \mathrm{x}^{2} & =850040.18 \\
\mathrm{n} & =3 \\
\mathrm{x}_{\mathrm{mi}} & =431.32 \\
\mathrm{x}_{\mathrm{ma}} & =623.2\end{aligned}$ & $\begin{aligned} \mathrm{x} & =727.06 \\
\mathrm{sx} & =50.1 \\
\sigma \mathrm{x} & =40.9 \\
\Sigma \mathrm{x} & =2181.2 \\
\Sigma \mathrm{x}^{2} & =1590898 \\
\mathrm{n} & =3 \\
\mathrm{x}_{\mathrm{mi}} & =672.4 \\
\mathrm{x}_{\mathrm{ma}} & =770.8\end{aligned}$ & $\begin{aligned} \mathrm{x} & =\mathbf{1 4 4 3 . 2} \\
\mathrm{sx} & =173.56 \\
\sigma \mathrm{x} & =141.71 \\
\Sigma \mathrm{x} & =4329.6 \\
\Sigma \mathrm{x}^{2} & =6308725.7 \\
\mathrm{n} & =3 \\
\mathrm{x}_{\mathrm{mi}} & =1312 \\
\mathrm{x}_{\mathrm{ma}} & =1640\end{aligned}$ \\
\hline 1350 & $\begin{aligned} \mathrm{x} & =\mathbf{8 6 . 4 1} \\
\mathrm{sx} & =22.31 \\
\sigma \mathrm{x} & =18.22 \\
\Sigma \mathrm{x} & =259.25 \\
\Sigma \mathrm{x}^{2} & =23399.57 \\
\mathrm{n} & =3 \\
\mathrm{x}_{\mathrm{mi}} & =60.68 \\
\mathrm{x}_{\mathrm{ma}} & =100.4\end{aligned}$ & $\begin{aligned} \mathrm{x} & =\mathbf{3 1 7 . 0 6} \\
\mathrm{sx} & =57.59 \\
\sigma \mathrm{x} & =47.02 \\
\Sigma \mathrm{x} & =951.2 \\
\Sigma \mathrm{x}^{2} & =308228.16 \\
\mathrm{n} & =3 \\
\mathrm{x}_{\mathrm{mi}} & =262.4 \\
\mathrm{x}_{\mathrm{ma}} & =377.2\end{aligned}$ & $\begin{aligned} \mathrm{x} & =\mathbf{7 7 0 . 8} \\
\mathrm{sx} & =232.51 \\
\sigma \mathrm{x} & =189.84 \\
\Sigma \mathrm{x} & =2312.4 \\
\Sigma \mathrm{x}^{2} & =1890519 \\
\mathrm{n} & =3 \\
\mathrm{x}_{\mathrm{mi}} & =590.4 \\
\mathrm{x}_{\mathrm{ma}} & =1033.2\end{aligned}$ & $\begin{aligned} \mathbf{x} & =\mathbf{1 6 5 0} \\
\mathrm{sx} & =368.66 \\
\sigma \mathrm{x} & =301.01 \\
\Sigma \mathrm{x} & =4952.8 \\
\Sigma \mathrm{x}^{2} & =8448571 \\
\mathrm{n} & =3 \\
\mathrm{x}_{\mathrm{mi}} & =1246.4 \\
\mathrm{xma} & =1968\end{aligned}$ \\
\hline
\end{tabular}

HA-ceramics sintered at different temperatures but made from the same HA-powder and with identical specifications except for characteristics dependent on the sintering process itself, i.e. microporosity, crystallite size, and grain size. The roughness parameters were similar. The sintering temperatures selected ranged from the minimal temperature required to obtain a bulk material $\left(850^{\circ} \mathrm{C}\right)$ to the maximum temperature not leading to thermal decomposition of the HA.

To evaluate the effect of the degree of modification of the culture medium produced by the material, using the same culture medium cells were grown either in contact with the material or separated from it by a cytocompatible porous polycarbonate membrane.

\section{MATERIALS AND METHODS}

The disks were placed at the bottom of polystyrene wells (Nunc multidishes). Three disks from each group were used for each time period. The polystyrene well bottom was used as a negative control. Cells were grown in direct contact with three disks and also at a distance from the ceramic on porous membranes (cyclopore cell culture insert, Falcon) placed in contact with three other disks for several sintering temperatures and for each culture period. The calcium and phosphorus contents of the culture medium were determined throughout the culture period.

\section{Ha-disk manufacturing}

Pure HA-powder (Purity > 99\%, Bioland, Toulouse, France) was used to prepare a slurry. The granulometry range was $0-25 \mu \mathrm{m}$, the surface area $21.5 \mathrm{~m}^{2} / \mathrm{g}$, and the grain shape irregular.

The slurry consisted of a suspension of HA-powder in an aqueous solution containing a dispersing agent and $0.26 \%$ of a binding agent. The dry matter concentration was $71.5 \%$. The slurry was cast in special plaster molds to obtain $15 \mathrm{~mm}$ in diameter disks after sintering.

Eight groups of disks were made by sintering the slurry at $850^{\circ}, 950^{\circ}, 1050^{\circ}, 1150^{\circ}, 1200^{\circ}, 1250^{\circ}, 1300^{\circ}$, and $1350^{\circ} \mathrm{C}$. The sintering temperature was reached after a $2^{\circ} \mathrm{C}$ increase $/ \mathrm{h}$ and then was maintained for $2 \mathrm{~h}$.

\section{Characterization and quality control}

\section{Spectroscopy}

The specifications of the ceramic disks were checked against a control material made at the same time as the tested material. The powdered disks were character-

TABLE IB

Growth Rate of the L-929 Fibroblastic Cell Line Grown on HA-Ceramics Sintered at Different Temperatures Between 24 and $144 \mathrm{~h}$ of Culture

\begin{tabular}{cc}
\hline Samples & $\begin{array}{c}\text { Growth Rate } \\
\left(\mathrm{h}^{-1}\right)\end{array}$ \\
\hline Control & 0.0093 \\
$850^{\circ} \mathrm{C}$ & -0.0023 \\
$950^{\circ} \mathrm{C}$ & -0.001 \\
$1050^{\circ} \mathrm{C}$ & 0.0073 \\
$1150^{\circ} \mathrm{C}$ & 0.0078 \\
$1200^{\circ} \mathrm{C}$ & 0.0086 \\
$1250^{\circ} \mathrm{C}$ & 0.0094 \\
$1300^{\circ} \mathrm{C}$ & 0.0085 \\
$1350^{\circ} \mathrm{C}$ & 0.0077 \\
\hline
\end{tabular}


ized by quantitative $\mathrm{X}$-ray diffraction and infrared spectrometry (Perkin Elmer 1600 FTIR). X-ray diffraction patterns were recorded on a Phillips goniometer TW 1050. X-ray emission was obtained by a cobalt anode (lambda $=1.78892 \AA$ ). Trace elements contained in the ceramics were measured with an Inductive Coupled Plasma technique (Perkin Elmer, Plasma 40 Emission Spectrometer) and were consistent with the ASTM F 1185-88 standard (Standard Specification for Composition of Ceramic Hydroxyapatite for Surgical Implants).

Surface analysis

Disk roughness parameters $\left(R_{a}, R_{p}, R_{t}\right)$ were determined using a microrugosimeter (Mitutoyo 407 microrugosimeter). SEM observations of the ceramic disk were carried out using a field emission SEM (Hitachi 4000 ) at $5 \mathrm{kV}$, the samples previously having been coated with gold-palladium.

\section{Testing method}

Cell culture

An L929 mouse-established fibroblast cell line was used. The cell line was grown to confluence in a Petri dish in DMEM medium (Gibco, France) supplemented with $5 \%$ fetal calf serum (IBF, France) and $2 \mathrm{mM}$ glutamine. The cells then were resuspended in the culture medium using a trypsine solution (Gibco, France). The wells containing HA-disks with or without a coating of polycarbonate membranes were inoculated with 1 $\mathrm{mL}$ of the suspension solution at a density of $10^{5}$ cells / $\mathrm{mL}$. The culture medium was changed twice a week. The cells then were grown for $24 \mathrm{~h}$ to 15 days.

At the end of the culture period, the disks and membranes were washed with PBS and the cells suspended in trypsine solution and counted in a Malassez's hemocytometer. The cell line growth rate $(\mu)$ was defined as $\mathrm{dN} / \mathrm{N}=\mu \mathrm{dt}$ or $\mu=\log \left(\mathrm{N} / \mathrm{N}_{0}\right) / \Delta \mathrm{t}$.

HA-disks sintered at different temperatures $\left(850^{\circ}\right.$, $950^{\circ}, 1050^{\circ}, 1150^{\circ}, 1200^{\circ}, 1250^{\circ}, 1300^{\circ}$, and $1350^{\circ} \mathrm{C}$ ) were placed on the bottom of polystyrene wells. Three replicates were used for each time period and for each temperature.

Another group of disks sintered at $850^{\circ}, 1150^{\circ}$, and $1250^{\circ} \mathrm{C}$ was handled in the same way except that a porous polycarbonate membrane (Millipore) was placed on each disk. Three replicates were used for each time period and for each temperature.

The time course of live-cell adhesion to the HA-disk was evaluated. One $\mathrm{mL}$ of a cell suspension $\left(10^{5}\right.$ cells / $\mathrm{mL}$ ) was poured into polystyrene wells containing an HA-disk of each sintering temperature group. The cul- ture media were removed and replaced after $30 \mathrm{~min}$ periods (from $30-180 \mathrm{~min}$ ) by a $0.1 \%$ neutral red solution in PBS for $5 \mathrm{~min}$. Then, using a light microscope in reflected light mode, cells that had captured the neutral red were counted per surface area unit.

An SEM of the cells grown on $850^{\circ} \mathrm{C}$ and $1200^{\circ} \mathrm{C}$ sintered ceramics was performed after 3 days of culture. The disks were washed in PBS, immersed in Karnovsky's fixative, dehydrated in alcohol and acetone, critical point dried, gold-palladium coated, and examined with a JEOL JST 200 scanning electron microscope at $25 \mathrm{kV}$.

\section{Exchange with the culture medium}

Culture medium calcium and phosphorus content

HA-disks sintered at different temperatures were immersed in $1 \mathrm{~mL}$ of culture medium (minus the fetal calf serum) without being inoculated with cells and then were incubated at $37^{\circ} \mathrm{C}$ for the same time period as the cultured disks. The culture medium then was diluted with deionized water and the calcium and phosphorus contents of the solution measured by Inductive Coupled Plasma Spectrometry (Perkin Elmer, Plasma 40 Emission Spectrometer) after oxidation of the organic matrix contained in the culture medium.

Evaluation of the surface area available for exchange with the culture medium

The evolution of the relative surface area, as dependent on the sintering temperature, was evaluated by way of the amount of protein adsorbed from a proteic solution onto disks of identical weight. HA-disks sintered at the specified temperatures were immersed for $24 \mathrm{~h}$ in an albumin solution $(1 \mathrm{mg} / \mathrm{mL})$ at $4^{\circ} \mathrm{C}$. The adsorbed proteins were desorbed for $48 \mathrm{~h}$ in an EDTA solution $(4 \% \mathrm{w} / \mathrm{v})$ by immersion of each disk in $5 \mathrm{~mL}$ of the solution at $4^{\circ} \mathrm{C}$. Some of the solution $(100 \mu \mathrm{L})$ then was mixed with $1 \mathrm{~mL}$ of a Coomasie Brilliant blue solution in $0.15 \mathrm{M} \mathrm{NaCl}$. The $\mathrm{A}_{595}$ was measured using a 1-cm pathlength microcuvette $(1 \mathrm{~mL})$.

\section{Statistical analysis}

Data were analyzed for statistical significance using an analysis of variance (ANOVA). Differences at $P$ values of less than 0.05 were considered significant.

\section{RESULTS}

\section{Characterization of the samples to be investigated}

X-ray and IR spectrometry confirmed that the disks were made of HA (Fig. 1). The disks sintered at $850^{\circ} \mathrm{C}$ 

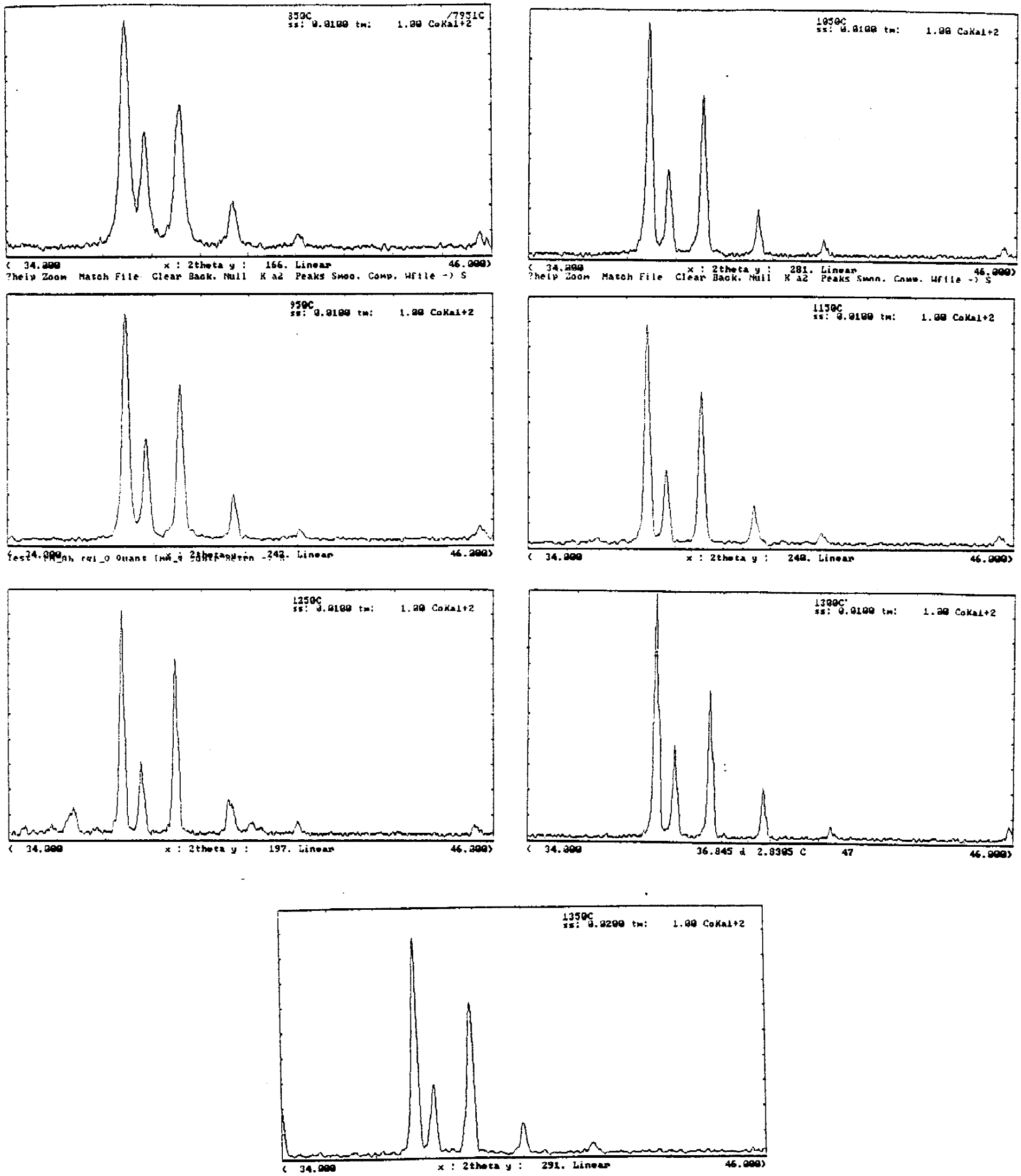

Figure 1. X-ray diffraction pattern of the different HA-ceramic disks.

consisted of small elongated grains linked by narrow grain boundaries forming a porous structure. They were $0.15-0.26 \mu \mathrm{m}$ in length and $0.04-0.06 \mu \mathrm{m}$ in width (Fig. 2) with a very high microporosity between the grains. The size of the micropores ranged from a fraction of the grain size to $0.2 \mu \mathrm{m}$ in diameter. The roughness parameters were: $R_{a}, 1.3 \mu \mathrm{m} ; R_{t}, 14 \mu \mathrm{m}$; and
$R_{p}, 3.9 \mu m$ (Fig. 3). X-ray spectroscopy revealed the presence of an amorphous phase and that the crystalline phase consisted of pure HA (Fig. 1). The roughness parameters of the $1150^{\circ} \mathrm{C}$ sintered disks were: $R_{a}$, $1.7 \mu \mathrm{m} ; \mathrm{R}_{\mathrm{t}}, 14.7 \mu \mathrm{m}$; and $\mathrm{R}_{\mathrm{p}}, 3.9 \mu \mathrm{m}$ (Fig. 3).

The $1200^{\circ} \mathrm{C}$ sintered disks consisted of larger grains of polygonal shape and were 0.8 to $2 \mu \mathrm{m}$ in size. As 


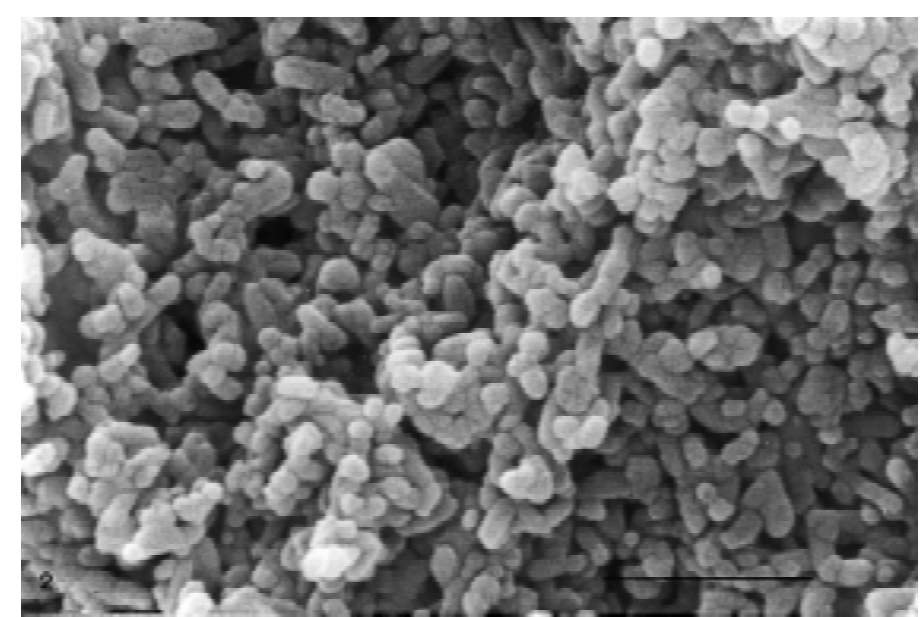

Figure 2. SEM of the ceramic grains of the $850^{\circ} \mathrm{C}$ sintered disks showing small grains with small grain boundaries and empty spaces constituting a microporosity between the grains. Bar: $1 \mu \mathrm{m}$.

they were very close together there was very little porosity (Fig. 4). The roughness parameters of the $1250^{\circ} \mathrm{C}$ sintered disks were: $R_{a}, 1.6 \mu \mathrm{m} ; R_{t}, 10.1 \mu \mathrm{m}$; and $\mathrm{R}_{\mathrm{p}}, 2.9 \mu \mathrm{m}$ (Fig. 3).

The amorphous phase no longer was apparent between $1050^{\circ} \mathrm{C}$ and $1350^{\circ} \mathrm{C}$ (Fig. 1). A small amount of TCP was present in the $1250^{\circ} \mathrm{C}$ sintered disks (Fig. 1).

\section{Cell growth}

In contact with disk

The rate of cell growth on the ceramics during the first $270 \mathrm{~h}$ was lower than the growth rate on the control material except for the $1250^{\circ} \mathrm{C}$ sintered disks. Growth rate on the $850^{\circ}$ and $950^{\circ} \mathrm{C}$ sintered disks was negative, indicating a decrease in cell number [Table

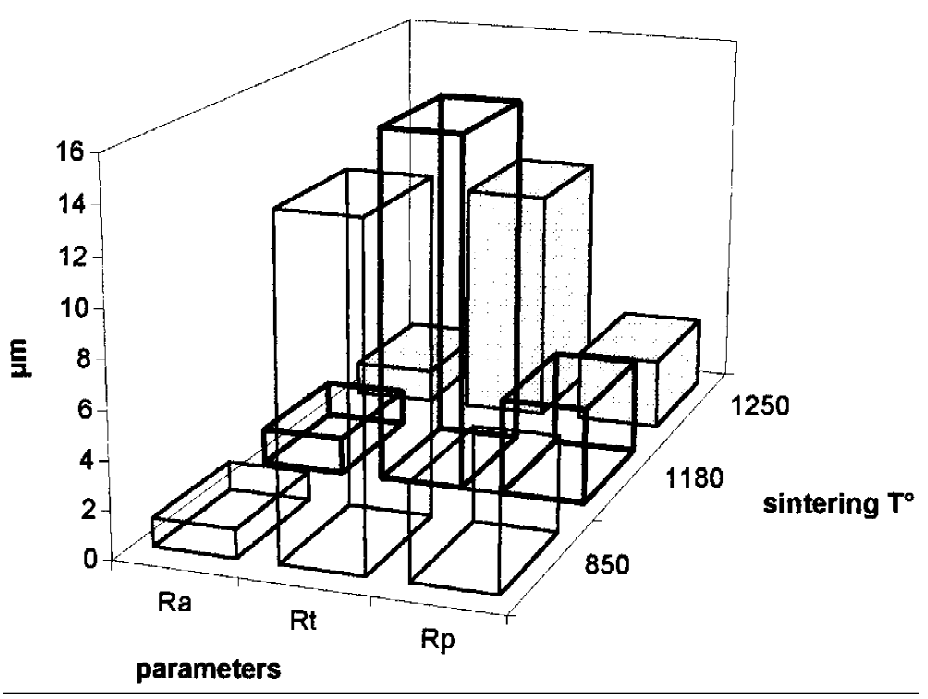

Figure 3. Roughness parameters measured on HA-disks sintered at three different temperatures.

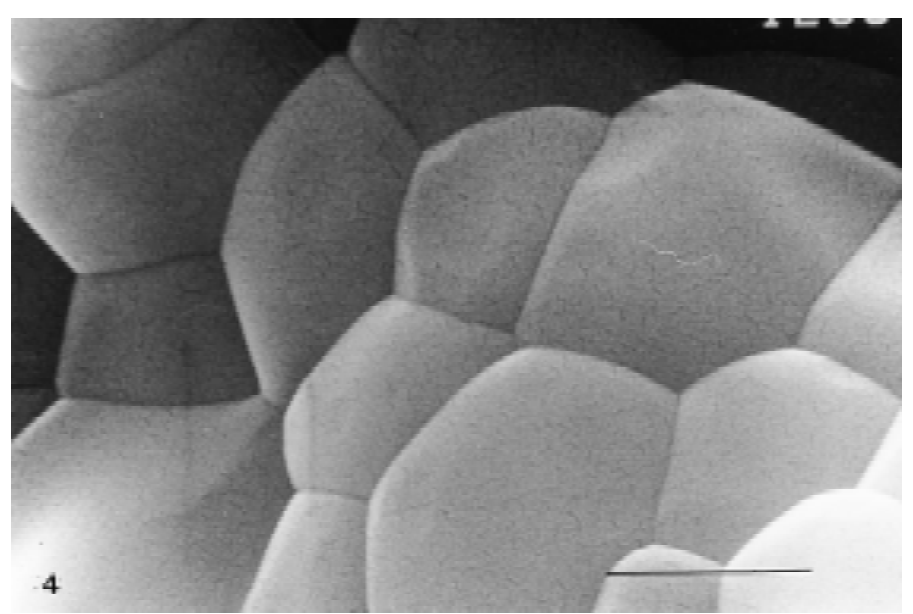

Figure 4. SEM of the ceramic grains of a $1250^{\circ} \mathrm{C}$ sintered ceramic. The grains are much bigger and polygonal. Very few spaces are found between the grains, making the ceramic density high. Bar: $1 \mu \mathrm{m}$.

I(A, B) and Fig. 5]. Growth rate on the disk surface during the 24-144 $\mathrm{h}$ period was lower than on the controls for all the other disks except the $1350^{\circ} \mathrm{C}$ ones.

The stationary phase was reached at $144 \mathrm{~h}$ on the control material but not attained in samples sintered at $1350^{\circ}, 1300^{\circ}, 1250^{\circ}$, or $1200^{\circ}$ even when the cell density obtained at the end of the culture period was higher than that on the control. The growth rate of the $1050^{\circ} \mathrm{C}$ samples was significantly lower than that on disks sintered at higher temperatures throughout the culture period.

The low-temperature disks $\left(850^{\circ}\right.$ and $\left.950^{\circ} \mathrm{C}\right)$ could be differentiated from the ceramic groups made up of high-temperature disks by the cell number obtained after $72 \mathrm{~h}$ (Fig. 5) using the Newman-Keuls test. The cell density on the surface in both groups was significantly different from that of the control material and other temperature-sintered disks. The cell density attained at $144 \mathrm{~h}$ permitted differentiation of the $850^{\circ}$ and $950^{\circ} \mathrm{C}$ ceramic groups from those consisting of ceramics sintered at temperatures between $1050^{\circ}$ and $1350^{\circ} \mathrm{C}$. Both groups were significantly different from the control material.

A third group constituted of $1050^{\circ} \mathrm{C}$ sintered ceramics appeared to be significantly different from the two former groups at 144 and $336 \mathrm{~h}$. At these times the control material could not be differentiated from the high-temperature sintered ceramics. There was a correlation between growth rate and sintering temperature (correlation coefficient $r=0.86$ ).

Not in direct contact with disk

Cell growth on membranes in contact with disks sintered at $850^{\circ} \mathrm{C}$ was lower than on membranes in contact with control materials during the culture period (Fig. 6). The cell growth rate on membranes in 


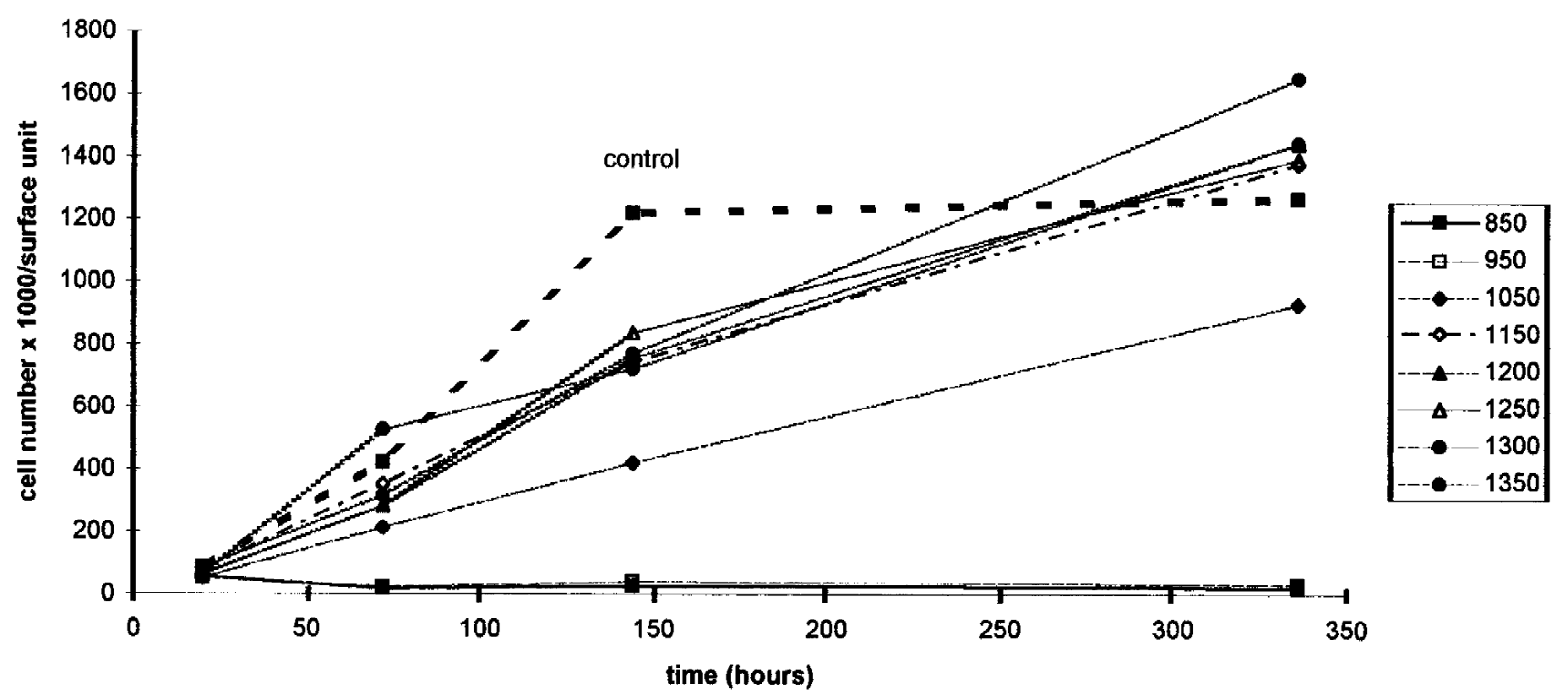

Figure 5. Growth curves at the ceramic contact.

wells containing $1180^{\circ}$ and $1250^{\circ} \mathrm{C}$ sintered disks was not significantly different at the end of the culture period from that of the control (Fig. 6 and Table II).

Two groups could be differentiated, according to the Newmann-Keuls test, from the cell densities obtained on the membranes on contact with the disks after 96 and $244 \mathrm{~h}$ : disks sintered at high temperatures $\left(1180^{\circ}\right.$ and $\left.1250^{\circ} \mathrm{C}\right)$, which had a high cell number, and disks sintered at the lowest temperature $\left(850^{\circ} \mathrm{C}\right)$, which had a significantly lower cell number. Both ceramic groups could be differentiated from the control at $96 \mathrm{~h}$.

Nevertheless cell growth was inhibited on membranes on contact with the $850^{\circ} \mathrm{C}$ sintered disks.

\section{Cell adhesion}

Cell adhesion to the ceramics during the first minutes of culture did not differ significantly among any of the ceramic samples (Fig. 7).

\section{Cell morphology}

SEM observation of cells grown for 3 days on the $850^{\circ}$ and $1250^{\circ} \mathrm{C}$ sintered disks showed a high-density layer of widely spread cells on the $1250^{\circ} \mathrm{C}$ sintered disks [Fig. 8(A)] and a nonhomogeneous layer of cells fusiform in aspect, mixed with cell debris on the $850^{\circ} \mathrm{C}$

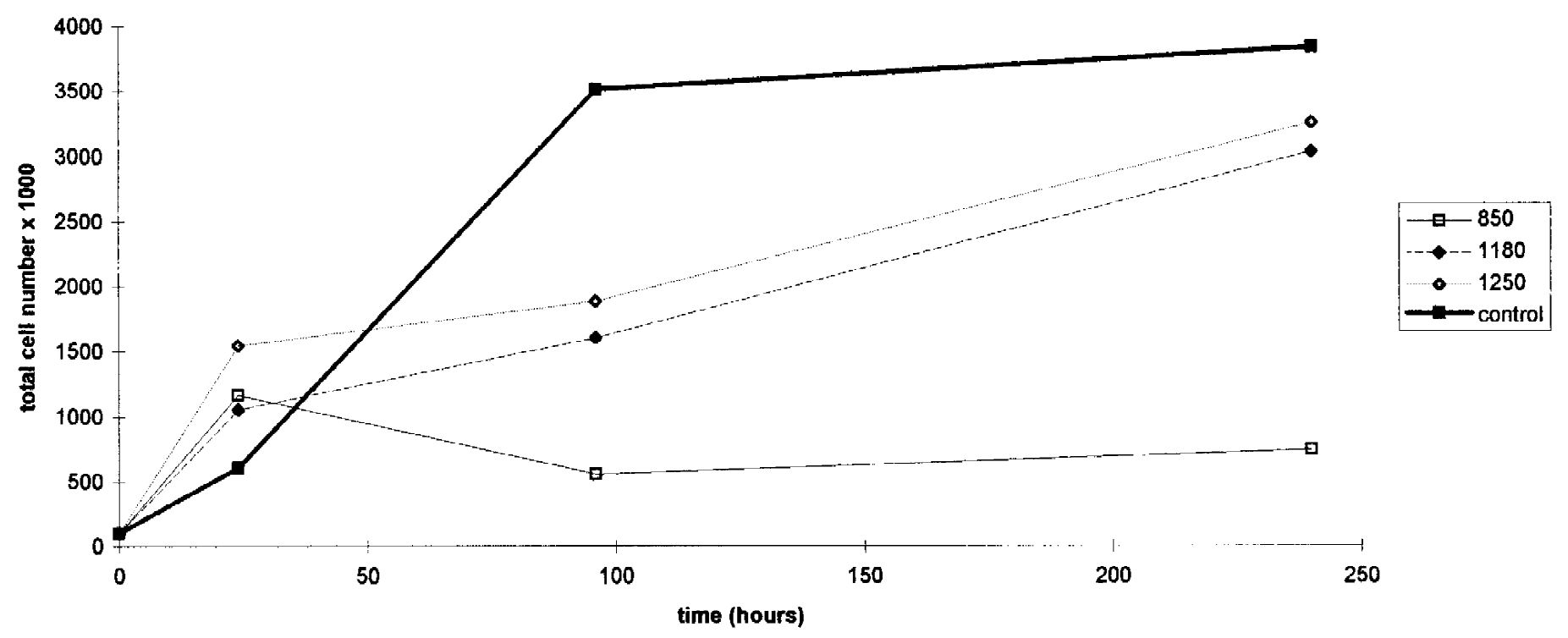

Figure 6. Growth of the cell line on permeable membranes settled on HA-disks sintered at different temperatures. 
TABLE II

Parametric Mean (x) of Cell Number Obtained at Each Period of Time on the Polycarbonate Membrane Settled on Disks Sintered at Different Temperatures

\begin{tabular}{|c|c|c|c|}
\hline Samples & 24 Hours & 96 Hours & 244 Hours \\
\hline Control & $\begin{aligned} \mathrm{x} & =\mathbf{6 0 6 . 6 6} \\
\mathrm{sx} & =115.57 \\
\sigma \mathrm{x} & =94.35 \\
\Sigma \mathrm{x} & =1820 \\
\Sigma \mathrm{x}^{2} & =1130850 \\
\mathrm{n} & =3 \\
\mathrm{x}_{\mathrm{mi}} & =485 \\
\mathrm{x}_{\mathrm{ma}} & =715\end{aligned}$ & $\begin{aligned} \mathrm{x} & =\mathbf{3 5 0 0} \\
\mathrm{sx} & =200 \\
\sigma \mathrm{x} & =163.29 \\
\Sigma \mathrm{x} & =10500 \\
\Sigma \mathrm{x}^{2} & =36830000 \\
\mathrm{n} & =3 \\
\mathrm{x}_{\mathrm{mi}} & =3300 \\
\mathrm{x}_{\mathrm{ma}} & =3700\end{aligned}$ & $\begin{aligned} \mathrm{x} & =\mathbf{3 8 3 3} \\
\mathrm{sx} & =850.49 \\
\sigma \mathrm{x} & =694.42 \\
\Sigma \mathrm{x} & =11500 \\
\Sigma \mathrm{x}^{2} & =45530000 \\
\mathrm{n} & =3 \\
\mathrm{x}_{\mathrm{mi}} & =3200 \\
\mathrm{x}_{\mathrm{ma}} & =4800\end{aligned}$ \\
\hline 850 & $\begin{aligned} \mathbf{x} & =\mathbf{1 1 6 6 . 6} \\
\mathrm{sx} & =131.5 \\
\sigma \mathrm{x} & =107.36 \\
\Sigma \mathrm{x} & =3500 \\
\Sigma \mathrm{x}^{2} & =4117918 \\
\mathrm{n} & =3 \\
\mathrm{x}_{\mathrm{mi}} & =1035 \\
\mathrm{x}_{\mathrm{ma}} & =1298\end{aligned}$ & $\begin{aligned} \mathrm{x} & =\mathbf{5 6 1 . 3 3} \\
\mathrm{sx} & =17.5 \\
\sigma \mathrm{x} & =14.29 \\
\Sigma \mathrm{x} & =1684 \\
\Sigma \mathrm{x}^{2} & =954898 \\
\mathrm{n} & =3 \\
\mathrm{x}_{\mathrm{mi}} & =544 \\
\mathrm{x}_{\mathrm{ma}} & =579\end{aligned}$ & $\begin{aligned} \mathrm{x} & =\mathbf{7 4 5 . 6 6} \\
\mathrm{sx} & =412.5 \\
\sigma \mathrm{x} & =336.8 \\
\Sigma \mathrm{x} & =2237 \\
\Sigma \mathrm{x}^{2} & =2008369 \\
\mathrm{n} & =3 \\
\mathrm{x}_{\mathrm{mi}} & =333 \\
\mathrm{x}_{\mathrm{ma}} & =1158\end{aligned}$ \\
\hline 1180 & $\begin{aligned} \mathbf{x} & =\mathbf{1 0 5 2 . 6 6} \\
\mathrm{sx} & =245.5 \\
\sigma \mathrm{x} & =200.45 \\
\Sigma \mathrm{x} & =3158 \\
\Sigma \mathrm{x}^{2} & =3444862 \\
\mathrm{n} & =3 \\
\mathrm{x}_{\mathrm{mi}} & =807 \\
\mathrm{x}_{\mathrm{ma}} & =1298\end{aligned}$ & $\begin{aligned} \mathbf{x} & =\mathbf{1 6 0 5} \\
\mathrm{sx} & =44 \\
\sigma \mathrm{sx} & =35.92 \\
\Sigma \mathrm{x} & =4815 \\
\sum \mathrm{x}^{2} & =7731947 \\
\mathrm{n} & =3 \\
\mathrm{x}_{\mathrm{mi}} & =1561 \\
\mathrm{x}_{\mathrm{ma}} & =1649\end{aligned}$ & $\begin{aligned} \mathrm{x} & =\mathbf{3 0 3 5} \\
\mathrm{sx} & =281 \\
\sigma \mathrm{sx} & =229.43 \\
\Sigma \mathrm{x} & =9105 \\
\Sigma \mathrm{x}^{2} & =27791597 \\
\mathrm{n} & =3 \\
\mathrm{x}_{\mathrm{mi}} & =2754 \\
\mathrm{x}_{\mathrm{ma}} & =3316\end{aligned}$ \\
\hline 1250 & $\begin{aligned} \mathbf{x} & =\mathbf{1 5 4 4} \\
\mathrm{sx} & =298 \\
\sigma \mathrm{x} & =243.31 \\
\Sigma \mathrm{x} & =4632 \\
\Sigma \mathrm{x}^{2} & =7329416 \\
\mathrm{n} & =3 \\
\mathrm{x}_{\mathrm{mi}} & =1246 \\
\mathrm{x}_{\mathrm{ma}} & =1842\end{aligned}$ & $\begin{aligned} \mathbf{x} & =\mathbf{1 8 8 6} \\
\mathrm{sx} & =9 \\
\sigma \mathrm{x} & =7.34 \\
\Sigma \mathrm{x} & =5658 \\
\Sigma \mathrm{x}^{2} & =10671150 \\
\mathrm{n} & =3 \\
\mathrm{x}_{\mathrm{mi}} & =1877 \\
\mathrm{x}_{\mathrm{ma}} & =1895\end{aligned}$ & $\begin{aligned} \mathbf{x} & =\mathbf{3 2 5 4 . 6 6} \\
\mathrm{sx} & =166 \\
\sigma \mathrm{x} & =135.53 \\
\Sigma \mathrm{x} & =9764 \\
\Sigma \mathrm{x}^{2} & =31833678 \\
\mathrm{n} & =3 \\
\mathrm{x}_{\mathrm{mi}} & =3089 \\
\mathrm{x}_{\mathrm{ma}} & =3421\end{aligned}$ \\
\hline
\end{tabular}

$\mathrm{sx}=$ variance; $\sigma \mathrm{x}=$ standard deviation; control $=$ bottom of the polystyrene well. sintered disks [Fig. 8(B)]. The cell density on the samples sintered at low temperatures was lower than that on the high-temperature samples.

\section{Exchange with culture medium \\ Calcium and phosphorus content of the culture medium}

The calcium and phosphorus contents of the culture medium were modified by the addition of HA-disks [Fig. 9(A, B)]. The initial calcium concentration of the culture medium was markedly decreased by the $850^{\circ}$ and $950^{\circ} \mathrm{C}$ disks and increased by the $1050^{\circ}$ to $1350^{\circ} \mathrm{C}$ disks. The lowest variations observed were in culture media containing the $1300^{\circ}$ and $1350^{\circ} \mathrm{C}$ sintered disks. The initial phosphorus concentration was modified in the same way, and the lowest modifications were observed in media containing the $1300^{\circ}$ and $1350^{\circ} \mathrm{C}$ ceramics.

The change in $\mathrm{Ca} / \mathrm{P}$ ratio brought about by the variation in $\mathrm{Ca}$ and $\mathrm{P}$ concentrations in the culture media did not fit with the nucleation of a stochiometric calcium phosphate, particularly for the $850^{\circ}-950^{\circ} \mathrm{C}$ sintered samples (Table III).

Amount of albumin desorbed from the ceramic

The optical density of the solution containing the albumin desorbed from the different disks indicated that the amount of desorbed proteins decreased as the sintering temperature increased (Fig. 10).

\section{DISCUSSION}

This study shows that in vitro HA-ceramics were able to modify the growth rate of cell lines grown in

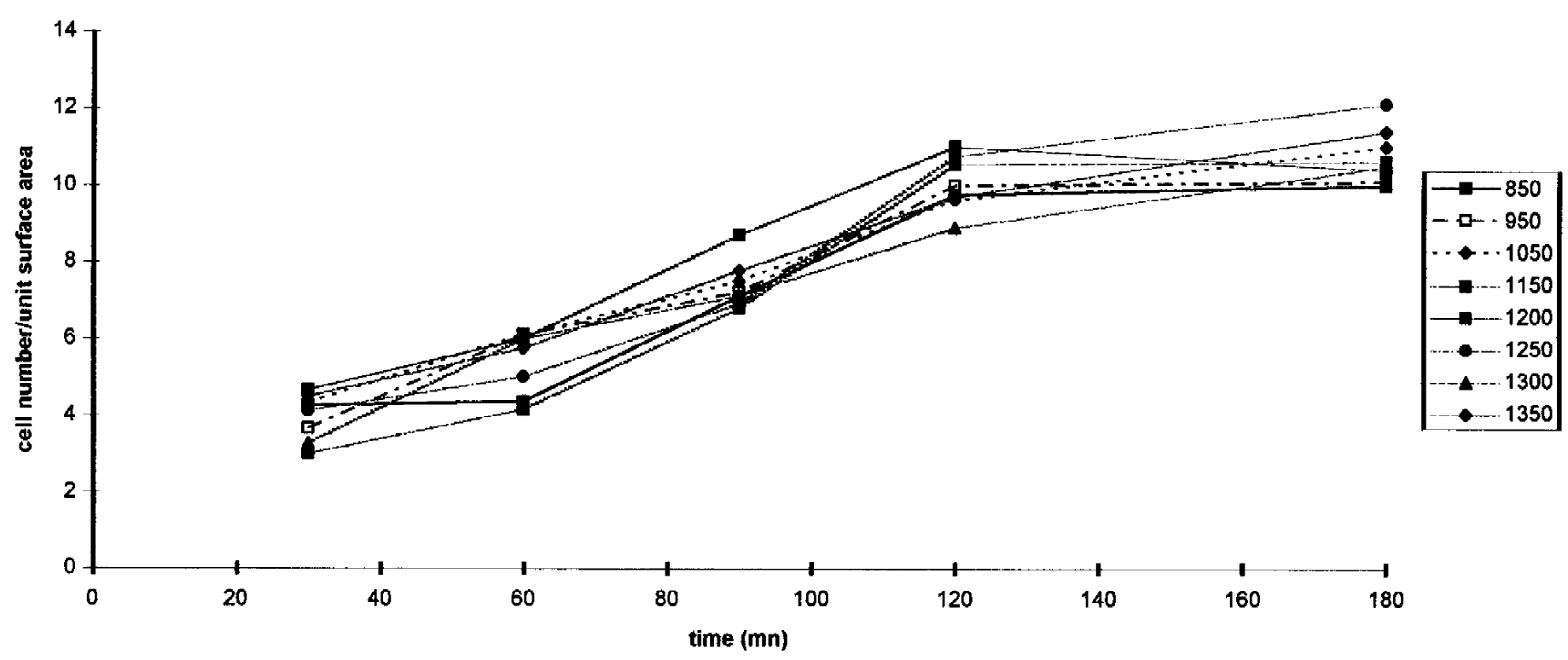

Figure 7. Cell adsorption on HA-ceramics sintered at different temperatures. 

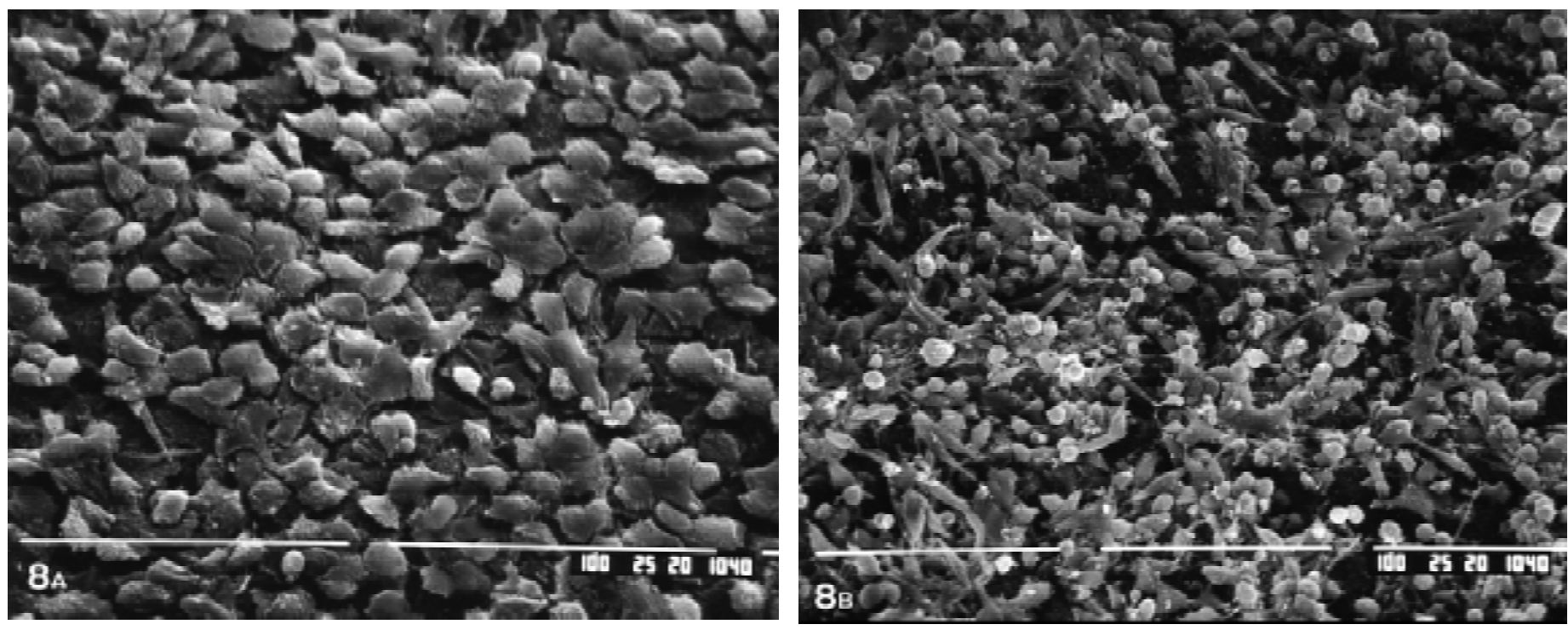

Figure 8. (A) Cells grown on a $1250^{\circ} \mathrm{C}$ sintered ceramic for 3 days. Cells are spread out over the ceramic surface forming several layers. Bar: $100 \mu \mathrm{m}$. (B) Cells grown 3 days on an $850^{\circ} \mathrm{C}$ sintered ceramic. Spindle-shaped or round cells can be seen at the ceramic surface. The cell density is lower and many cells are detached from the ceramic. Bar $100 \mu \mathrm{m}$.

(A)

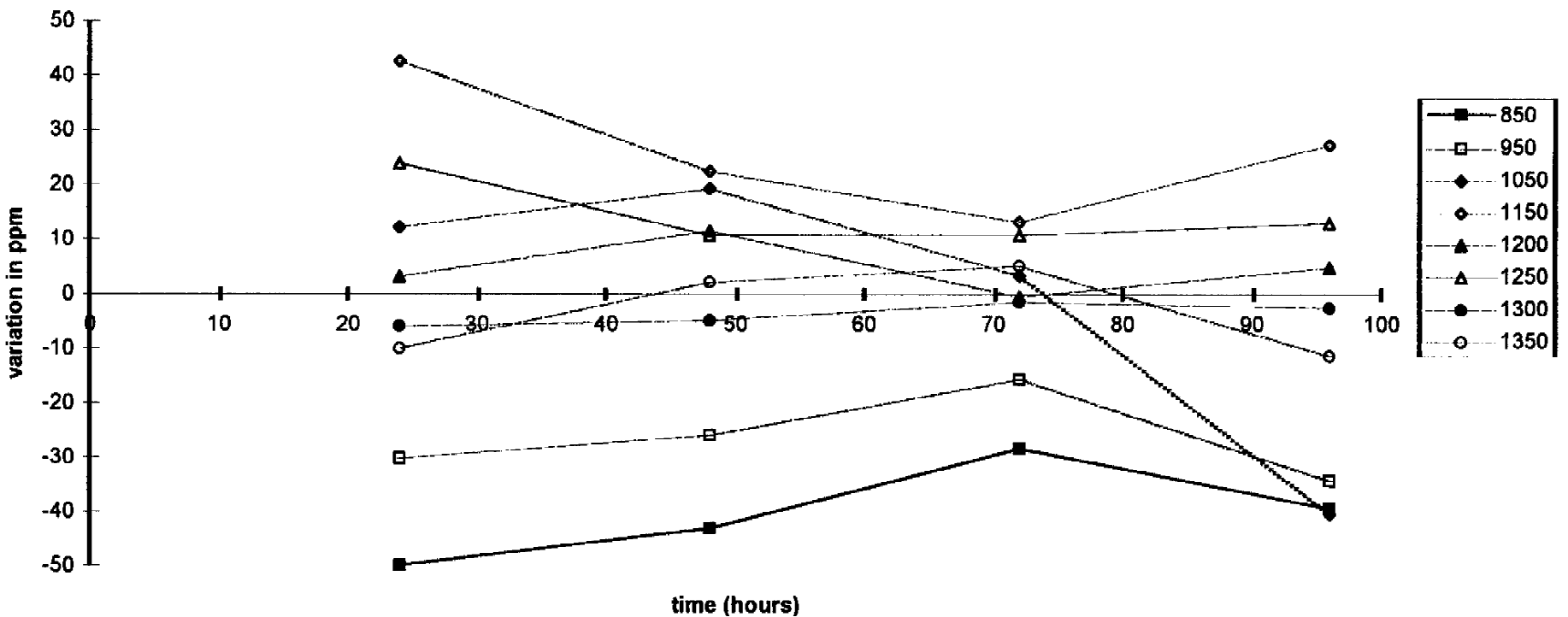

(B)

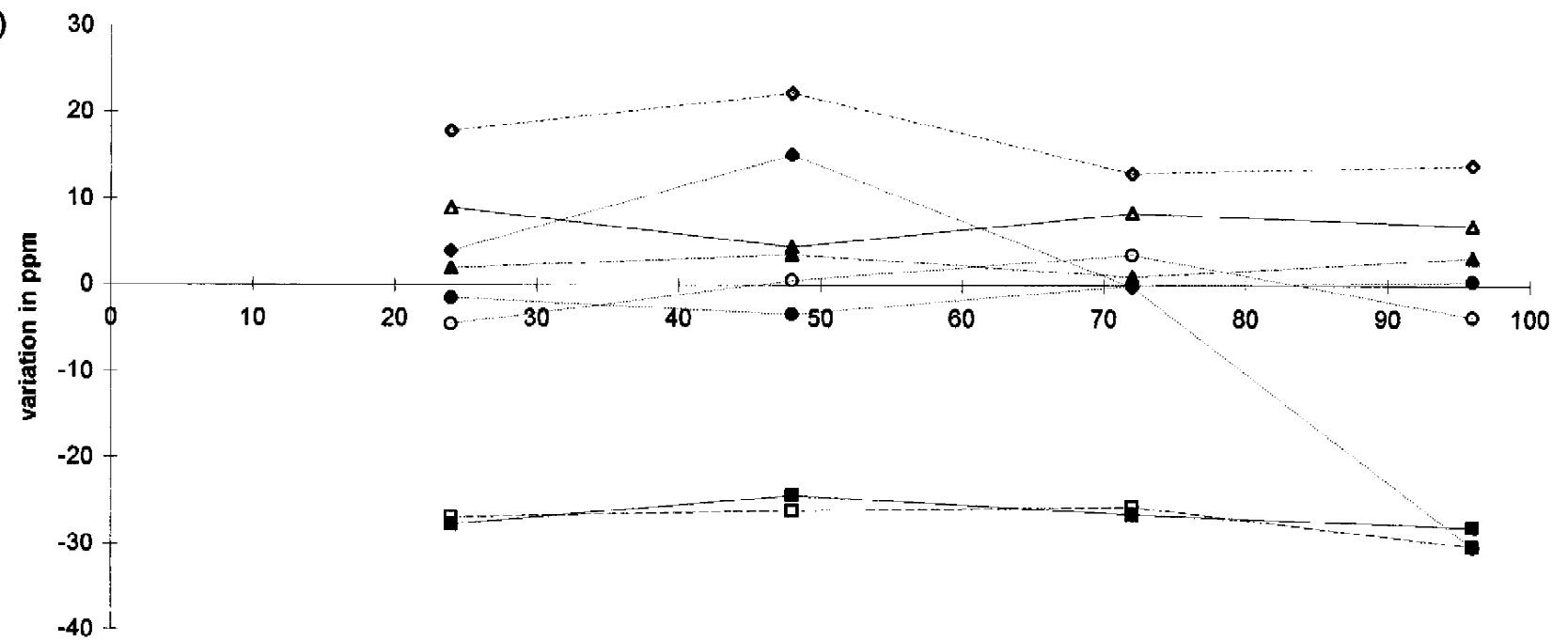

time (hours)

Figure 9A. Variation in the Ca concentration of the culture medium in the presence of HA-ceramic sintered at different temperatures. B. Variation in the P concentration of the culture medium in the presence of HA-ceramics sintered at different temperatures. 


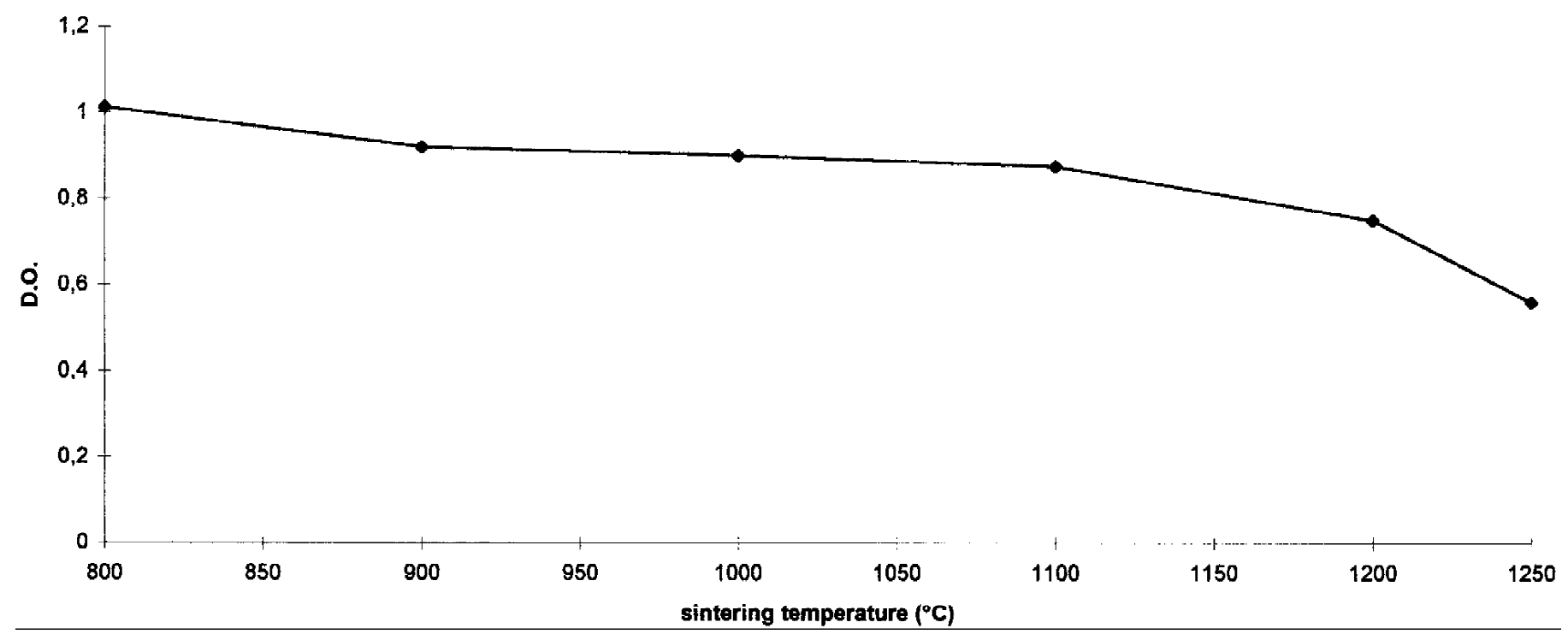

Figure 10. Albumin fixation on HA-ceramic sintered at different temperatures measured by Coomasie brilliant blue method.

contact with them. The growth rate of a fibroblastic cell line was correlated to the sintering temperatures of the HA-ceramic support. This ability to influence a cell line's biological characteristics appears to depend on the surface-related characteristics of the HAceramic. The cells did not need to be in contact with the material surface to have their growth rate decreased, thus suggesting that the actual culture medium had been modified by the HA-ceramic. Ca and P concentrations in culture media in contact with the ceramic were determined, and the observed decrease in $\mathrm{Ca}$ and $\mathrm{P}$ concentrations in media that had been in contact with the $850^{\circ}$ to $1050^{\circ} \mathrm{C}$ sintered ceramics suggests that the low concentrations of both elements might be the determining factor in cell growth-rate modification.

These results are consistent with those reported by Hyakuna et al. ${ }^{6}$ The increase in the surface area of inert material (in a powdered form) implanted in the peritoneal cavity of mice made that material toxic and led to the death of the animal because they were un-

TABLE III

$\mathrm{Ca} / \mathrm{P}$ Ratios of the Differences in Ca and $\mathbf{P}$ Concentrations of the Culture Medium in Contact with HA-Ceramic Disks

\begin{tabular}{ccccr}
\hline $\begin{array}{c}\text { Sintering } \\
\text { Temp. } \\
\left({ }^{\circ} \mathrm{C}\right)\end{array}$ & 24 Hours & 48 Hours & 72 Hours & 96 Hours \\
\hline 850 & 1.399 & 1.373 & 0.832 & 1.092 \\
950 & 0.872 & 0.771 & 0.474 & 0.881 \\
1050 & 2.36 & 0.989 & -26.280 & 1.036 \\
1150 & 1.845 & 0.782 & 0.779 & 1.514 \\
1200 & 1.240 & 2.485 & -0.388 & 1.139 \\
1250 & 2.062 & 1.856 & 0.986 & 1.444 \\
1300 & 3.205 & 1.139 & 122.45 & -4.191 \\
1350 & 1.904 & 2.726 & 1.098 & 2.438 \\
\hline
\end{tabular}

able to maintain the appropriate concentration of certain extracellular liquid ions. ${ }^{7}$

As shown by examination of the ceramic disks in our study, the same phenomenon occurred. Grain size increased with the sintering temperature, disk porosity decreased, and the surface in contact with the culture medium was reduced, as was shown by the lower amount of protein adsorbed onto ceramics produced at higher sintering temperatures. The exchange between the ceramic and the culture medium evolved in relation to the surface area. The high surface area was responsible for a smaller amount of $\mathrm{Ca}$ and $\mathrm{P}$ in the culture medium, which, presumably, is used for secondary nucleation of carbonated apatite at the HA surface. The balance between the dissolution and the reprecipitation process occurring at the surface of the materials sintered above $1050^{\circ} \mathrm{C}$ favored dissolution as the amount of $\mathrm{Ca}$ and $\mathrm{P}$ in the culture medium increased. It is suggested from the variation in the $\mathrm{Ca} / \mathrm{P}$ ratio observed during the culture period for each sintering temperature that the dissolution/ reprecipitation process occurring at the surface of the material evolved throughout the culture period.

The physicochemical events occurring at the interface between calcium phosphate materials are thought to be responsible for the chemical bonding of bioactive implants with bone. LeGeros et al. ${ }^{8}$ summarized these events as: (1) decrease in the $\mathrm{pH}$ in the environment of the calcium phosphate ceramics causing partial dissolution of the ceramic macrocrystal; (2) increase in the concentration of calcium and phosphate ions in the micro-environment; (3) formation of $\mathrm{CO}^{3-}$ apatite crystals ${ }^{9}$ (by precipitation, by transformation from one Ca-P phase to another, or by seeded growth) incorporating ions (e.g., carbonate, magnesium) from the biological fluids; (4) association of the $\mathrm{CO}^{3-}$ apatite microcrystals with an organic matrix; and (5) incorpora- 
tion of these microcrystals with the collagenous matrix during the formation of new bone at the interface. Based on this process, the balance of ions between stages (1), (2), and (3) would be related directly to the surface of the ceramic grains. Standard tests for cytotoxicity do not involve direct cell culture on the material but rather disposal of the material in contact with a confluent cell layer grown in a Petri dish. ${ }^{10}$ The growth of a cell line on the material surface seems to be a very useful means of evaluating the cytotoxicity of a material when the cells are able to adhere to the material, as is the case with HA-ceramics. Care must be taken, however, to determine the precise characteristics of the material and how they influence the cell culture environment; cell-culture testing is carried out in a closed environment, and thus any environmental modification brought about by the material may lead to misinterpretation of its cytocompatibility. HAceramics sintered at low temperatures and implanted in animals are not cytotoxic because the medium can buffer the ion variations induced by the material when it is implanted in such an open environment.

These results suggest that there is a need for further study of the influence of HA-ceramic characteristics on the biological behavior of cells and tissue in contact with them. Very few of these characteristics have been evaluated. Pore sizes and variations in the ceramic content in various calcium phosphate phases have been studied independently. To obtain the best possible osseointegration in poorly osteogenic sites, the influence of other ceramic characteristics and combinations of characteristics still needs to be defined despite the fact that these materials have been used in human surgery for a decade. Cytocompatibility testing as defined in the ISO, ASTM, or CE standards may reflect very different mechanisms of material action on cell metabolism, and the results of such evaluations may be more difficult to interpret than is supposed.

\section{CONCLUSIONS}

Basic cell functions, such as growth rate, of a cell line grown on HA-ceramics may be modified by certain characteristics of the ceramic. Grain size and the existence of porosity inside the material were shown to modify the cytocompatibility of HA-devices tested in vitro, possibly because they changed the surface area of the material and the degree of exchange with the culture medium. Such results raise the question of the validity of extrapolating in vitro cytocompatibility testing results for in vivo use. In our experiment, the cytotoxicity of the low-temperature sintered ceramics is to be considered artifactual and due to the culture conditions. It is a cause of concern for the interpretation of such testing when it is performed for determination of the biocompatibility of a device submitted to the ISO 10993-1 standard (Biological evaluation of medical devices-Part 1: Guidance on selection of tests).

\section{References}

1. M. Jarcho, "Calcium phosphate ceramics as hard tissue prosthetics," Clin. Orthop. Rel. Res., 157, 259-278 (1981).

2. F. B. Bagambisa and U. Joos, "Preliminary studies on the phenomenological behaviour of osteoblasts cultured on hydroxyapatite ceramics," Biomaterials, 11, 5056 (1990).

3. H. S. Cheung and M. Haak, "Growth of osteoblasts on porous calcium phosphate ceramic: An in vitro model for biocompatibility study," Biomaterials, 10, 63-67 (1989).

4. J. M. Sautier, J. R. Nefussi, and N. Forest, “Ultrastructural study of bone formation on synthetic hydroxyapatite in osteoblast cultures," Cells and Mater., 1, 209-217 (1991).

5. J. D. De Bruijn, C. P. A. T. Klein, K. de Groot, and C. A. van Blitterswijk, "The ultrastructure of the bone hydroxyapatite interface in vitro," J. Biomed. Mater. Res., 26, 1365-1382 (1992a).

6. K. Hyakuna, T. Yamamuro, Y. Kotoura, Y. Kakutani, T. Kitsugi, H. Takagi, H. Oka, and T. Kokubo, "The influence of calcium phosphate ceramics and glass-ceramics on cultured cells and their surrounding media," $J$. Biomed. Mater. Res., 23, 1049-1066 (1989).

7. K. Kawanabe, T. Yamamuro, T. Nakamura, and S. Kotani, "Effect of injecting massive amounts of bioactive ceramics in mice," J. Biomed. Mater. Res., 25, 117-128 (1991).

8. R. Z. LeGeros, I. Orly, M. Gregoire, and G. Daculsi, "Substrate surface dissolution and interfacial biological mineralization," in The Bone-Biomaterial Interface, J. E. Davies (ed.), University of Toronto Press, Toronto 1991, pp. $76-88$.

9. M. Heughebaert, R. Z. LeGeros, M. Gineste, A. Guilhem, and G. Bonel, "Physico-chemical characterization of deposits associated with HA-ceramics implanted in nonosseous sites," J. Biomed. Mater. Res., 22, 257-268 (1988).

10. Biological evaluation of medical devices. Part 5: Tests for cytotoxicity: In vitro methods, International Standard ISO 10993-5.

11. P. S. Eggli, W. Müller, and R. K. Schenk, "Porous hydroxyapatite and tricalcium phosphate cylinders with two different pore sizes implanted in the cancellous bone of rabbits. A comparative histomorphometric and histologic study of bony ingrowth and implant substitution," Clin. Orthop. Rel. Res., 238, 127-137 (1988). 